\title{
EFEKTIVITAS EDUKASI GIZI DENGAN PENDAMPINGAN TERHADAP ASUPAN ZAT GIZI MAKRO, HbA1c, DAN PROFIL LIPID DARAH PADA PASIEN DM TIPE II
}

\author{
Effectiveness of Nutrition Coaching on Carbohyrate and Fat Intake, as well as $\mathrm{HbA1c}$ and \\ Blood Lipid Profile of Type II DM Patients \\ Indah Ratnasari ${ }^{1}$, Iskari Ngadiarti' ${ }^{*}$, Lilik Fauziyah Ahmad ${ }^{2}$ \\ ${ }^{1}$ Program Studi Sarjana Terapan Gizi dan Dietetika, Jurusan Gizi, Poltekkes Kemenkes Jakarta II \\ 2Instalasi Gizi RSUPN Dr. Cipto Mangunkusumo \\ *E-mail: Ratnasari.indah712@gmail.com
}

\begin{abstract}
Medical nutritional therapy is an important part of the comprehensive management of type II DM. Good glycemic control can control blood lipid profile levels so that it can reduce the risk of complications of heart disease in people with type II diabetes. This study aims to determine whether education with assistance for 6 months affects macronutrient intake, HbA1c, and lipid profiles in patients with Type II diabetes. This study used a Quasi-Experimental design with experimental design The Pretest-Postest design without a control group. The sample used the purposive sampling method according to the inclusion and exclusion criteria with 30 samples. The research data were obtained from secondary data from the Endocrine Metabolic Poly and Nutritional Poly RSCM Research in 2017. The results showed that there was a significant effect $(p<0.05)$ of education with assistance for 6 months on the value of HbA1c, while with the intake of macronutrients (carbohydrates and fats), LDL and triglycerides had no significant effect $(p>0.05$ ). HBA1c levels in this study were significantly related to blood triglyceride levels. Therefore, it is necessary to carry out more research using nutrition education methods with assistance to working groups of young adults and the need to pay attention to compliance with medication consumption or the use of insulin therapy.
\end{abstract}

Keywords: macro nutrient intake, HbA1c, lipid profile, type II DM, coaching

\section{ABSTRAK}

Terapi gizi medik merupakan bagian penting dalam pengelolaan DM tipe II secara komprehensif. Kontrol glikemik yang baik dapat mengendalikan kadar profil lipid darah sehingga dapat menurunkan risiko komplikasi penyakit jantung pada penderita DM tipe II. Penelitian bertujuan mengetahui apakah edukasi dengan pendampingan selama 6 bulan mempengaruhi asupan zat gizi makro, nilai $\mathrm{HbA} 1 \mathrm{c}$ dan profil lipid pada pasien DM Tipe II. Penelitian ini menggunakan desain Quasi Eksperimental dengan desain eksperiment The Pretest- Postest design tanpa grup kontrol. Sampel menggunakan metode Purposive sampling sesuai dengan kriteria inklusi dan eksklusi dengan jumlah 30 orang. Data penelitian didapatkan dari data sekunder penelitian Poli Metabolik Endokrin dan Poli Gizi RSCM tahun 2017. Hasil penelitian menunjukkan ada pengaruh yang bermakna $(p<0.05)$ edukasi dengan pendampingan selama 6 bulan terhadap nilai $\mathrm{HbA1c}$, sedangkan dengan asupan zat gizi makro (karbohidrat dan lemak, LDL dan trigliserida tidak ada pengaruh yang signifikan $(p>0.05)$. Kadar HBA1c dalam penelitian ini berhubungan nyata dengan kadar tigliserida darah. Kesimpulan edukasi gizi dengan pendampingan selama 6 bulan kurang efektif mengendalikan perilaku makan dan kontrol lipid darah. Oleh karena itu perlu dilakukan penelitian lagi menggunakan metode edukasi gizi dengan pendampingan pada kelompok usia dewasa muda yang bekerja serta perlu diperhatian kepatuhan konsumsi obat-obatan atau penggunaan terapi insulin.

Kata kunci: asupan zat gizi makro, HbA1c, profil lipid, DM tipe II, pendampingan 


\section{PENDAHULUAN}

D iabetes Mellitus merupakan salah satu Penyakit Tidak Menular (PTM) yang menjadi ancaman serius bagi dunia, termasuk Indonesia. Saat ini, Indonesia merupakan negara peringkat keenam di dunia setelah Tiongkok, India, Amerika Serikat, Brazil dan Meksiko dengan jumlah penyandang diabetes tertinggi pada usia 20-79 tahun. ${ }^{1}$ Sejalan dengan hal tersebut, hasil Riset Kesehatan Dasar (Riskesdas) memperlihatkan peningkatan angka prevalensi Diabetes yang cukup signifikan, yaitu dari 6,9 persen di tahun 2013 menjadi 8,5 persen di tahun 2018. ${ }^{2}$ Angka kematian dan morbiditas pasien DM type II sebagian besar terjadi dengan penyulit Penyakit Jantung Koroner (PJK). Menurut America Heart Association pada Mei 2012, paling sedikit 65 persen penderita DM meninggal akibat penyakit jantung atau stroke. Selain itu, orang dewasa yang menderita DM berisiko dua sampai empat kali lebih besar terkena penyakit jantung dari pada orang yang tidak menderita DM. Salah satu upaya dalam rangka mengurangi risiko penyakit jantung koroner, maka dalam deteksi dini dan pengobatan Diabetes Mellitus perlu menggali penanda dislipidemia dan gangguan organ jantung. ${ }^{3}$

Risiko komplikasi diabetes dapat dikurangi atau dicegah dengan mengontrol kadar glukosa darah, tekanan darah dan profil lipid secara berkala. Menurut American Diabetes Association seseorang dikatakan berisiko terjangkit komplikasi diabetes jika memiliki kadar $\mathrm{HbA1c}>6,5$ persen, tekanan darah $\geq 140 / 90 \mathrm{mmHg}$ dan profil lipid yang tinggi (trigliserida $\geq 200 \mathrm{mg} / \mathrm{dl}$ ). Komplikasi diabetes yang sering terjadi yaitu komplikasi makrovaskular dan mikrovaskular. ${ }^{4}$ Profil darah tersebut dapat dikendalikan dengan 4 pilar pengelolaan DM meliputi edukasi, terapi gizi medik, olahraga, dan obat-obatan. Dalam menjalankan 4 pilar tersebut agar berjalan optimal diperlukan pendampingan. ${ }^{5}$ Hasil penelitian di Puskesmas Banyuanyar dan Balowerti menunjukan adanya pengaruh pendampingan terhadap kepatuhan diet dan kontrol gula darah pada lansia. Dalam upaya melaksanakan pengendalian penyakit DM, diperlukan pemahaman terkait pengelolaan penyakit diabetes di rumah, motivasi yang tinggi serta dukungan dari orang di sekitarnya.
Pendampingan dalam membantu pasien DM termasuk dalam katagori "coaching" yaitu membantu penderita DM untuk mengembangkan solusi dari mereka sendiri dan melatih proses berpikir sesuai dengan kondisinya sehingga dapat diterapkan secara mandiri untuk selanjutnya. Dengan kata lain pendampingan ini digunakan untuk mengoptimalkan tujuan terapi gizi medik pada penderita DM type II. Tujuan utama terapi gizi medik yang utama adalah memperbaiki kebiasaan makan sehingga dapat mengendalikan kadar glukosa darah, lemak darah, dan tekanan darah. ${ }^{6}$ Pada akhirnya diharapkan penderita DM patuh terhadap pengelolaan diet tanpa pendampingan petugas kesehatan sehingga risiko komplikasi DM dapat diturunkan. Waktu dalam pendampingan juga perlu diperhatikan. Waktu yang teralu cepat, memungkinkan belum terciptanya perubahan perilaku, sedangkan waktu yang terlalu lama menimbulkan kebosanan. Penelitian Zareban et all., (2014) di menunjukkan Self-care education program selama 3 bulan dapat merubah nilai HbA1C secara signifikan. ${ }^{7}$ Berbeda dengan penelitian yang dilakukan Zhang dan Chu (2018) melakukan pendampingan selama 2 tahun di Rumah Sakit Nanjing, China, didapatkan hasil penurunan LDL selama pendampingan namun hasilnya tidak signifikan secara statistik. ${ }^{8}$

Kadar glukosa yang terkontrol merupakan salah satu dampak dari kebiasaan makan yang baik. Salah satu penanda bahwa kadar gula darah terkontrol adalah dengan melihat nilai HBA1c $<6,5$ persen. Penelitian Hajime (2018) yang dilakukan pada lansia Jepang tanpa konsumsi obat anti-diabetik dan terapi diet, menyatakan bahwa terdapat hubungan yang positif antara asupan karbohidrat (g/hari) dengan kadar $\mathrm{HbA} 1 \mathrm{c} .{ }^{9}$

Asupan karbohidrat merupakan salah satu zat gizi yang dapat mempengaruhi kadar $\mathrm{HbA1C}$, sehingga menjadi bagian penting dalam pengendalian diabetes. Jumlah dan jenis karbohidrat yang dimakan dapat mempengaruhi kadar glukosa darah. Beberapa penelitian menyatakan bahwa asupan lemak juga turut mempengaruhi kadar $\mathrm{HbA} 1 \mathrm{c} .^{10}$ Koloverou et all., menyatakan bahwa asupan lemak yang tinggi terutama Short Faty Acid (SFA) dapat menyebabkan rusaknya insulin yang berakibat akan meningkatkan kadar HbA1c dalam darah. ${ }^{11}$ 
Profil lipid normal juga merupakan salah satu tujuan mengatur kebiasaan makan pada penderita DM. Asupan karbohidrat dan lemak, sebagai contoh, juga mempengaruhi kadar trigliserida dan LDL dalam darah. Berdasarkan penelitian Desi tahun 2018 didapatkan hubungan yang signifikan antara kadar trigliserida dengan asupan karbohidrat dan lemak. ${ }^{12} \mathrm{Hal}$ ini berkaitan dengan terjadinya komplikasi diabetes dikarenakan penambahan asupan karbohidrat berlebih dan kadar trigliserida tidak terkontrol. Kadar trigliserida dipengaruhi oleh asupan karbohidrat yang berlebih sehingga meningkatkan produksi kadar trigliserida di hati. ${ }^{13}$ Konsumsi kalori berlebih terutama yang berasal dari gula sederhana maka hati akan meningkatkan produksi kadar trigliserida. ${ }^{14}$ Dengan adanya peningkatan kadar trigliserida dan Low Density Lipoprotein (LDL) diketahui sebagai faktor risiko terjadinya aterosklerosis. ${ }^{15}$

Beberapa penelitian melaporkan bahwa DM dan penyakit kardiovaskular saling menyusul, artinya penderita berisiko tinggi menderita risiko penyakit kardiovaskular, demikian pula sebaliknya penyakit jantung koroner sangat mudah mendapat risiko DM. Oleh karena itu nilai $\mathrm{HbA} 1 \mathrm{c}$ dapat memprediksi risiko pengembangan komplikasi diabetes. Terlepas dari faktor risiko klasik seperti dislipidemia, peningkatan $\mathrm{HbA} 1 \mathrm{c}$ adalah faktor risiko independen untuk penyakit jantung koroner (PJK). Diperkirakan ada risiko 18 persen peningkatan PJK untuk setiap kenaikan 1 persen pada kadar $\mathrm{HbA} 1 \mathrm{C}$ absolut dalam populasi diabetes. Korelasi positif antara $\mathrm{HbA1c}$ dan PJK ini telah ditunjukkan pada kasus nondiabetes, bahkan dalam kisaran normal HbA1c. ${ }^{16}$ Berdasarkan penelitian Husain, Ali, ljaz dan Rahim Tahun 2017 pada 401 pasien afghan Di Rumah Sakit Umum \& Pusat Penelitian Northwest, Peshawar dihasilkan korelasi yang signifikan antara nilai $\mathrm{HbA} 1 \mathrm{C}$ dengan parameter lipid darah. ${ }^{17}$

Ditinjau dari berbagai latar belakang tersebut, peneliti ingin mengetahui apakah edukasi dengan pendampingan selama 6 bulan pada penderita DM dapat memperbaiki kebiasaan makanan terutama pemenuhan asupan zat gizi makro dan bagaimana efeknya terhadap pengendalian kadar gula darah yang diamati dari kadar $\mathrm{HbA} 1 \mathrm{c}$ dan profil lipid darah yang merupakan faktor risiko utamanya.

\section{METODE PENELITIAN}

Penelitian ini menggunakan desain Quasi Eksperimental dengan desain eksperimen The Pretest-Postest design tanpa grup kontrol. Jumlah sampel adalah 30 yang diambil dari 60 responden dengan rentang usia 30-65 tahun pada penelitian "efektifitas care coaching model sebagai upaya pemberdayaan pasien Diabetes untuk meningkatkan status kesehatan dan perilaku pengendalian Diabetes 2017" di Poli Endokrin dan Poli Gizi RSCM. Pendampingan dilakukan 2 kali sebulan dengan beberapa tema diskusi yang terkait dengan pengeloalan DM yaitu perilaku makan, aktifitas fisik, perilaku minum obat, strategi perubahan perilaku yang tidak biasa seperti puasa, perjalanan, perilaku pemeliharaan tubuh untuk menghindari komplikasi lanjutan DM. Lama pendampingan 60-90 menit per sesi.

Pemilihan 30 sampel diambil secara purposive sampling sesuai dengan kriteria inklusi dan eksklusi yang di tentukan oleh peneliti. Kriteria inklusi yang dipilih yaitu memiliki data yang lengkap pada penelitian sebelumnya, kadar $\mathrm{HbA} 1 \mathrm{c}>7,5$ persen, dan usia 30-60 tahun. Sedangkan kriteria eksklusinya yaitu memiliki penyakit penyerta yang mempengaruhi daya ingat dan memiliki berkas food record yang tidak lengkap. Data asupan karbohidrat dan lemak diperoleh melalui formulir food record $3 \times 24$ jam, kemudian divalidasi dengan food recall $3 \times 24$ jam. Pengambilan data food recall dilakukan oleh ahli gizi rumah sakit. Nilai HBA1c dilakukan dengan metode kromatografi ion dan profil lipid indirek presipitasi di Laboratorium Patologi Klinik RSCM.

Pengambilan data asupan zat gizi makro, $\mathrm{HbA1c}$ dan profil lipid dilakukan 3 kali, yaitu bulan awal sebelum dilakukan intervensi, tiga bulan setelah intervensi dan enam bulan setelah dilakukan intervensi. Analisis data untuk menguji pengaruh pendampingan terhadap perubahan asupan zayt gizi makro (asupan karbohidra dan lemak) dan nilai $\mathrm{HbA} 1 \mathrm{C}$ digunakan uji paired sampel $t$ test sedangkan untuk menguji hubungan antar variabel dugunakan uji korelasi Spearman Product Moment. Penelitian ini sudah mendapatkan izin etik penelitian dari FKUI-RSCM Nomor KET.1020/UN2.F1/ETIK/PPM.00.02/2019. 
Tabel 1

Karakteristik Responden

\begin{tabular}{lcc}
\hline Karakteristik & $\mathrm{n}$ & $\%$ \\
\hline $\begin{array}{c}\text { Perempuan } \\
-\quad \text { Jenis Kelamin }\end{array}$ & 10 & 33,3 \\
$-\quad$ Laki-laki & 20 & 66,7 \\
$\begin{array}{l}\text { Kelompok Usia (tahun) } \\
-\quad 30-35\end{array}$ & 1 & \\
$-\quad 36-45$ & 2 & 3,3 \\
$-\quad 46-55$ & 13 & 6,7 \\
$-\quad 56-65$ & 14 & 43,3 \\
Pekerjaan & 10 & 46,7 \\
$-\quad$ Bekerja & 20 & 33,3 \\
$-\quad$ Tidak Bekerja & & 66,7 \\
\hline
\end{tabular}

\section{HASIL}

Dari Tabel 1 mengenai karakteristik responden dapat diketahui bahwa sebagian besar pasien DM tipe 2 pada penelitian ini terdiri atas 66,7 persen berjenis kelamin perempuan, 46,7 persen berusia 56-65 tahun, dan 66,7 persen tidak bekerja.

Pada Tabel 2 diketahui bahwa sebelum dilakukan intervensi rata-rata asupan karbohidrat yaitu $181,30 \pm 46,16$ gram dengan nilai minimum 84,41 gram dan nilai maksimum 305,29 gram. Rata-rata asupan lemak $51,17 \pm 16,45$ gram dengan nilai minimum 20,02 gram dan nilai maksmum 83,84 gram. Rata-rata HbA1c $9,47 \pm 1,75$ persen dengan nilai minimum 7,1 persen dan nilai maksimum 14 persen. Rata-rata kadar trigliserida $173,40 \pm 63,73 \mathrm{mg} / \mathrm{dl}$ dengan nilai minimum $79 \mathrm{mg} / \mathrm{dl}$ dan nilai maksimum $318 \mathrm{mg} / \mathrm{dl}$. Rata-rata kadar LDL $136,76 \mathrm{mg} / \mathrm{dl}$ dengan nilai minimum $206 \mathrm{mg} / \mathrm{dl}$ dan nilai maksimum $206 \mathrm{mg} / \mathrm{dl}$.

Hasil penelitian yang disajikan pada Tabel 3 menunjukkan rata-rata perubahan asupan karbohidrat dan lemak, kadar $\mathrm{HbA} 1 \mathrm{c}$ serta profil lipid yang terjadi selama pendampingan berlangsung. Pada tiga bulan pertama terjadi peningkatan asupan karbohidrat ditandai dengan nilai rata-rata bernilai negatif $(-6,720)$. Dari hasil uji statistik t-test didapatkan t hitung ($0,792)>t$ tabel $(2,045)$ serta nilai $p=0,435>$ 0,05 sehingga dapat disimpulkan bahwa tidak ada perbedaan asupan karbohidrat yang bermakna pada tiga bulan pertama. Pada tiga bulan kedua terjadi penurunan asupan karbohidrat ditandai dari nilai rata-rata hitung positif $(4,278)$. Dari hasil uji yang telah dilakukan didapatkan $t$ hitung $(0,607)<t$ tabel $(2,042)$ dan nilai $p=0,548>0,05$ sehingga dapat disimpulkan bahwa tidak ada perbedaan asupan karbohidrat yang bermakna pada tiga buan kedua. Kemudian jika diakumulasikan selama 6 bulan pendampingan terjadi peningkatan asupan karbohidrat ditandai dengan nilai rata-rata hitung negatif $(-2,442)$. Dari hasil uji yang dilakukan didapatkan thitung $(-0,285)<t$ tabel $(2,045)$ dan nilai $p=0,778$ $>0,05$ maka dapat disimpulkan bahwa selama pendampingan tersebut tidak ada perbedaan asupan karbohidrat yang bermakna.

Pada tiga bulan pertama terjadi peningkatan asupan lemak ditandai dengan nilai rata-rata hitung bernilai negatif $(-0,195)$. Untuk mengetahui perubahan yang terjadi bermakna atau tidak, dilakukan uji statistik paired $t$ test. Dari hasil uji tersebut didapatkan $t$ hitung ($0,057)>t$ tabel $(2,045)$ serta nilai $p=0,955>$ 0,05 sehingga dapat disimpulkan bahwa tidak ada perbedaan asupan lemak yang bermakna pada tiga bulan pertama. Pada tiga bulan kedua terjadi peningkatan asupan lemak ditandai dari nilai rata-rata hitung negatif $(-0,684)$. Dari hasil uji yang telah dilakukan didapatkan $t$ hitung ($0,285)<t$ tabel $(2,045)$ dan nilai $p=0,778>0,05$ sehingga dapat disimpulkan bahwa tidak ada perbedaan asupan lemak yang bermakna pada tiga bulan kedua. Kemudian jika diakumulasikan selama 6 bulan pendampingan terjadi peningkatan asupan lemak ditandai dengan nilai rata-rata hitung negatif $(-0,879)$. Dari hasil uji yang dilakukan didapatkan $\mathrm{t}$ hitung $(-0,334)<\mathrm{t}$ tabel $(2,045)$ dan nilai $p=0,741>0,05$ maka dapat disimpulkan bahwa selama pendampingan tersebut tidak ada perbedaan asupan lemak yang bermakna. 
Tabel 2

Asupan Karbohidrat, Lemak, Kadar HbA1c, dan Profil Lipid sebelum Pendampingan

\begin{tabular}{lccc}
\hline Variabel & Mean \pm SD & Min & Max \\
\hline Karbohidrat & $181,30 \pm 46,16$ & 84,41 & 305,29 \\
Lemak & $51,17 \pm 16,45$ & 20,02 & 83,84 \\
HbA1c & $9,47 \pm 1,75$ & 7,10 & 14,00 \\
Trigliserida & $173,40 \pm 63,74$ & 79,00 & 318,00 \\
LDL & $136,77 \pm 30,91$ & 91,00 & 206,00 \\
\hline
\end{tabular}

Tabel 3

Perbedaan Asupan Karbohidrat, Lemak, dan Kadar Profil Lipid selama Pendampingan

\begin{tabular}{lccc}
\hline Asupan & Mean \pm SD & t-hitung & Nilai p \\
\hline Karbohidrat & & & \\
Bulan 0\&3 & $-6,720 \pm 46,49$ & $-0,792$ & 0,435 \\
Bulan 3\&6 & $4,278 \pm 35,59$ & 0,607 & 0,548 \\
Bulan 0\&6 & $-2,442 \pm 47,01$ & $-0,285$ & 0,778 \\
Rata-rata & $-1,628 \pm 43,03$ & $-0,156$ & 0,587 \\
Lemak & & & \\
Bulan 0\&3 & $-0,195 \pm 18,66$ & $-0,057$ & 0,955 \\
Bulan 3\&6 & $-0,684 \pm 13,14$ & $-0,285$ & 0,778 \\
Bulan 0\&6 & $-0,879 \pm 14,40$ & $-0,334$ & 0,741 \\
Rata-rata & $0,586 \pm 15,40$ & $-0,225$ & 0,825 \\
HbA1c & & & \\
Bulan 0\&3 & $1,737 \pm 2,22$ & 4,286 & 0,000 \\
Bulan 3\&6 & $-0,413 \pm 1,47$ & 1,546 & 0,133 \\
Bulan 0\&6 & $1,323 \pm 2,22$ & 3,272 & 0,003 \\
Rata-rata & $0,882 \pm 1,97$ & 3,034 & 0,045 \\
Trigliserida & & & \\
Bulan 0\&3 & $-10,167 \pm 73,602$ & $-0,757$ & 0,455 \\
Bulan 3\&6 & $9,800 \pm 55,071$ & 0,975 & 0,338 \\
Bulan 0\&6 & $-0,367 \pm 73,849$ & $-0,260$ & 0,978 \\
Rata-rata & $-0,245 \pm 67,50$ & $-0,014$ & 0,590 \\
LDL & & & \\
Bulan 0\&3 & $-2,867 \pm 40,37$ & $-0,389$ & 0,700 \\
Bulan 3\&6 & $5,067 \pm 32,77$ & 0,847 & 0,404 \\
Bulan 0\&6 & $8,469 \pm 46,39$ & 0,260 & 0,797 \\
Rata-rata & $3,556 \pm 39,84$ & 0,239 & 0,634 \\
\hline & & & \\
\hline
\end{tabular}




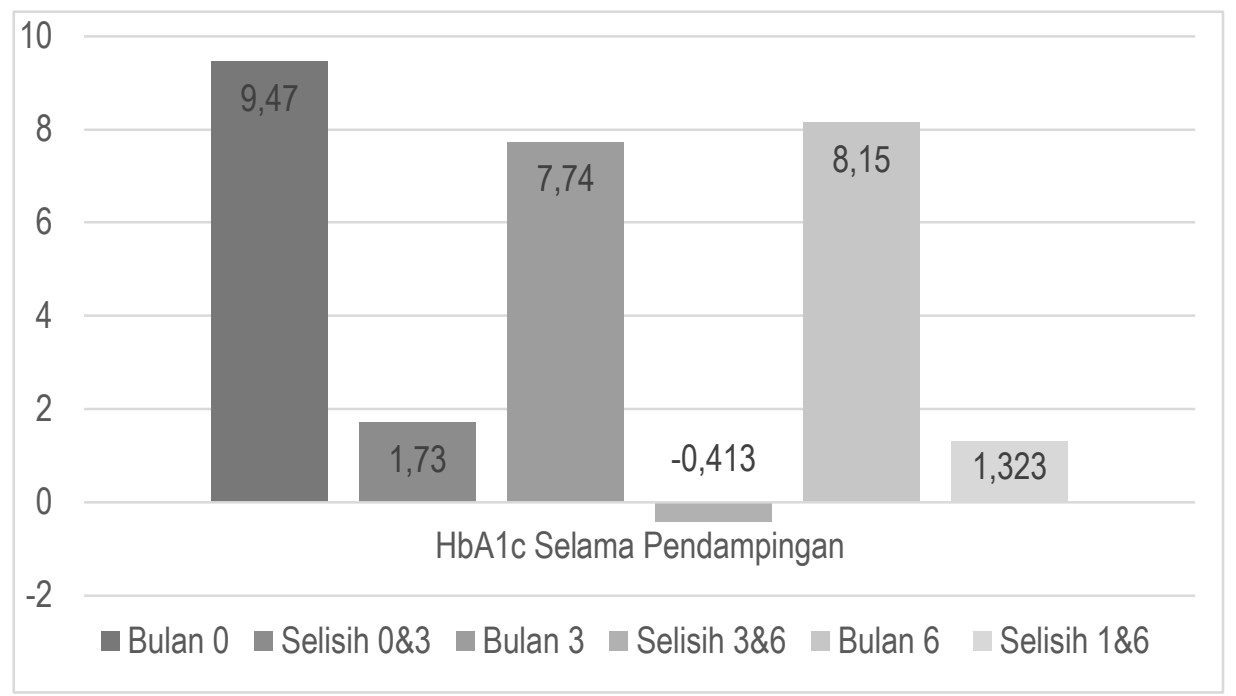

Gambar 1

Gambaran Kadar HbA1c serta Selisih Perubahan setelah Diberikan Pendampingan

Berdasarkan Gambar 1 dapat dilihat bahwa selama pendampingan berlangsung terjadi penurunan kadar $\mathrm{HbA} 1 \mathrm{c}$ pada tiga bulan pertama ditandai oleh rata-rata perubahan sebesar 1,737 $\pm 2,22$. Jika dihitung berdasarkan uji statistik didapatkan perubahan yang bermakna kadar HbA1c pada bulan ke-3, ditandai oleh $t$ hitung $(4,268)>t$ tabel $(2,045)$ serta nilai $p=0,000<0,05$. Pada tiga bulan kedua didapatkan peningkatan kadar $\mathrm{HbA} 1 \mathrm{c}$ ditandai dengan rata-rata sebesar $-0,413 \pm$ 1,47 .

Hasil uji statistik didapatkan $\mathrm{t}$ hitung ($1,546)<t$ tabel $(2,045)$ dan nilai $p=0,133>0,05$ sehingga dapat disimpulkan bahwa tidak ada perbedaan kadar $\mathrm{HbA} 1 \mathrm{C}$ yang bermakna pada tiga bulan kedua. Kemudian jika diakumulasikan selama 6 bulan pendampingan terjadi penurunan kadar $\mathrm{HbA} 1 \mathrm{C}$ ditandai dengan nilai rata-rata hitung positif $1,323 \pm 2,22$. Dari hasil uji yang dilakukan didapatkan thitung $(3,272)<$ t tabel $(2,045)$ dan nilai $p=0,003>0,05$ maka dapat disimpulkan bahwa selama pendampingan tersebut ada perbedaan kadar $\mathrm{HbA1C}$ yang bermakna.

Berdasarkan pemantauan kadar trigliserida didapatkan bahwa terjadi peningkatan kadar trigliserida selama tiga bulan pertama ditandai dengan rata-rata bernilai $-10,167 \pm 73,602$. Dihitung dengan uji statistik $\mathrm{t}$ test didapatkan $\mathrm{t}$ hitung $(-0,757)<t$ tabel $(2,045)$ serta nilai $p=0,455>0,05$ sehingga dapat diketahui bahwa tidak ada perbedaan kadar trigliserida yang bermakna. Pada tiga bulan kedua dapat dilihat pada tabel 2 bahwa terjadi penurunan kadar trigliserida ditandai dengan rata-rata bernilai positif sebesar 9,800 $\pm 55,071$. Namun, jika dihitung berdasarkan uji statistik didapatkan $\mathrm{t}$ hitung $(0,975)<t$ tabel $(2,045)$ dan nilai $p=0,338$ $>0,05$ yang artinya tidak ada perbedaan kadar trigliserida yang bermakna bulan ke-6. Jika diakumulasikan selama 6 bulan pendampingan disimpulkan bahwa terjadi peningkatan kadar trigliserida ditandai dengan rata-rata kenaikan sebesar $-0,367 \pm 73,849$. Hasil uji statistik didapatkan thitung $(-0,027)<\mathrm{t}$ tabel $(2,045)$ dan nilai $p=0,978>0,05$ maka dapat disimpulkan bahwa selama pendampingan tersebut tidak ada perbedaan kadar trigliserida yang bermakna.

Selama pendampingan, kadar LDL mengalami perubahan baik peningkatan 
maupun penurunan. Pada tiga bulan pertama didapatkan peningkatan kadar LDL ebesar $2,867 \pm 40,37$. Dari hasil uji statistik didapatkan tidak ada perbedaan nilai LDL yang bermakna pada bulan ke-3, ditandai oleh $t$ hitung $(-0,389)$ $<\mathrm{t}$ tabel $(2,045)$ serta nilai $p=0,700>0,05$. Pada tiga bulan kedua terjadi penurunan kadar LDL sebesar 5,067 $\pm 32,77$. Hasil uji statistik didapatkan thitung $(0,847)<\mathrm{t}$ tabel $(2,045)$ dan nilai $p=0,404>0,05$ sehingga dapat disimpulkan bahwa tidak ada perbedaan kadar LDL yang bermakna pada bulan ke-6. Jika diakumulasikan selama 6 bulan pendampingan diketahui bahwa terjadi penurunan kadar LDL sebesar $8,469 \pm 46,39$. Namun, dari hasil uji statistik diketahui bahwa $t$ hitung $(-0,260)<\mathrm{t}$ tabel $(2,045)$ dan nilai $p=0,797>0,05$ maka dapat disimpulkan bahwa selama pendampingan tersebut tidak ada perbedaan kadar LDL yang bermakna.

\section{BAHASAN}

\section{Pengaruh edukasi dengan pendampingan terhadap asupan karbohidrat dan lemak}

Data dasar asupan sebelum dilakukan intervensi menunjukan bahwa rata-rata asupan karbohidrat dan lemak masih dalam rentang normal berdasarkan Angka Kecukupan Gizi menurut umur dan jenis kelamin. Rata-rata asupan karbohidrat sebesar 181,30 $\pm 46,16$ gram, rata-rata ini masih masuk dalam rentang normal yaitu 275-340 gram dan rata-rata asupan lemak sebesar $51,17 \pm 16,45$ gram, ratarata ini masih masuk dalam renatang normal yaitu $\quad 50-60$ gram. ${ }^{18}$ Setelah dilakukan intervensi, terjadi perubahan asupan karbohidrat dan lemak namun perubahan tersebut secara statistik tidak bermakna. Hasil ini sejalan dengan penelitian Latifani (2016), bahwa tidak ada perbedaan asupan sebelum dan sesudah diberikan konseling baik menggunakan modul maupun tidak. ${ }^{19}$

Pada penelitian ini responden diberikan intervensi berupa edukasi dan coaching yang dilakukan selama 6 bulan. Edukasi gizi anjuran makanan yang tepat bagi pasien diabetes disampaikan oleh ahli gizi. Kemudian dilakukan monitoring berupa perubahan asupan, kadar $\mathrm{HbA} 1 \mathrm{c}$ dan profil lipid. Namun, belum terlihat adanya perubahan asupan secara signifikan. Berdasarkan hasil catatan record, masih ditemukannya asupan makanan pokok $>7$ porsi/hari dan konsumsi $>8$ jenis makanan yang digoreng/hari. Menurut Teori Lawrence Green (1980) menyatakan bahwa perilaku kesehatan manusia dipengaruhi oleh tiga faktor yaitu faktor predisposisi, faktor pendukung dan faktor pendorong. ${ }^{20}$ Faktor predisposisi yang diwujudkan dalam pengetahuan sudah difasilitasi dengan peningkatan pengetahuan melalui edukasi. Faktor pendorong yang diwujudkan dalam sikap perilaku petugas sudah dilakukan melalui konseling dan coaching. Faktor pendorong beberapa sudah diwujudkan dalam pemberian alat test gula, dan obat-obatan namun makanan tidak. Dengan kata lain makanan diharapkan responden mampu melakukan modofikasi sendiri atau dengan keluarga berdasarkan hasil edukasi dan pendampingan.

Selain itu, dalam pengambilan data record asupan sangat bergantung pada kejujuran dan keterampilan mencatat. $\mathrm{Hal}$ ini sangat berpengaruh dikarenakan responden dalam penelitian ini lebih banyak dengan kategori lansia akhir. Untuk itu dipertegas kembali dengan food recall 24 jam. Akan tetapi hal ini masih menjadi kendala, responden masih ada yang tidak mengingat dengan apa yang di konsumsi, hal ini juga berkaitan dengan karalkteristik responden yang sebaghian besar berusia diatas 56-65 tahun. Dalam Undang undang No. 13 tahun 1998 usia tersebut masuk katagori pra lansia dan lansia.

\section{Pengaruh edukasi pendampingan terhadap kadar $\mathrm{HbA1c}$}

Pendampingan selama 3 bulan lebih efektif dalam mengendalikan nilai $\mathrm{HbA} 1 \mathrm{C}$ dibandingkan pendampingan selama 6 bulan. Penelitian ini diperkuat dengan penelitian yang dilakukan oleh Zareban et all., (2014) di mana hasil penelitiannya menunjukkan terdapat perubahan kadar $\mathrm{HbA} 1 \mathrm{c}$ yang signifikan selama 3 bulan setelah dilakukan Self-care education program. $^{7}$

Lamanya waktu pendampingan selama 6 bulan membuat responden merasa bosan sehingga kebiasaan makan yang sudah mulai dibentuk kembali lagi ke awal yaitu dengan masih tingginya asupan makanan pokok dan gorengan yang menyebabkan meningkatnya asupan karbohidrat dan lemak. Hal ini diperkuat oleh konsep kekambuhan, dimana individu akan kembali kambuh ke posisi awal setelah 3 bulan 
atau ke posisi awal setelah 3 bulan atau lebih. ${ }^{21}$ Selain itu, mayoritas responden dalam penelitian ini masuk ke dalam golongan lansia yang tidak bekerja sehingga memiliki ketergantungan tinggi terhadap keluarga terkait pemenuhan asupan makan. ${ }^{22}$ Edukasi dengan pendampingan dilakukan dengan pendekatan "non directif" yang tujuannya perubahan perilaku makan dilakukan atas kesadaran diri sendiri, nampaknya lebih tepat diberikan pada masyarakat yang ada kemandirian dalam sosial ekonomi. ${ }^{23}$

$\mathrm{HbA1c}$ dapat dikendalikan dengan memperbaiki kebiasaan makan sesuai dengan diet diabetes, penggunaan obat hiperglikemik oral, dan terapi insulin. ${ }^{24},{ }^{25}$ Penelitian ini hanya melihat dari sisi perubahan kebiasaan makannya saja, sehingga penurunan $\mathrm{HbA} 1 \mathrm{c}$ yang terjadi diduga disebabkan oleh faktor lain seperti penggunaan obat, dan terapi insulin. Sebuah studi mengatakan bahwa penggunaan obat hipoglikemik oral secara rutin diketahui dapat menurunkan 0,4-2,5 persen HbA1c. Terapi insulin yang diberikan secara parenteral juga memiliki keefektifan menurunkan kadar HbA1C sampai 4,9 persen. ${ }^{25}$ Dan terapi yang lebih baik yaitu menggambungkan pengobatan dan pengaturan makan. Studi di Inggris menunjukkan bahwa hanya dengan pengaturan makan saja dapat menurunkan kadar $\mathrm{HbA} 1 \mathrm{C}$ dari 9 persen menjadi 7 persen. ${ }^{24}$ Akan tetapi pasien lebih cenderung memilih obat-obatan, obat medis maupun tradisional dibandingkan dengan menjaga makanan dengan diet dikarenakan efek yang dihasilkan cukup signifikan dan membutuhkan waktu yang lebih cepat dibandungkan dengan pengaturan makan. Pembatasan makanan sering kali menjadi kendala tersendiri bagi pasien diabetes. Pasien masih sulit mongontrol godaan untuk mengonsumsi makanan yang dapat memperburuk keadaan seperti makanan manis, tepung-tepungan dan gorengan atau dengan sengaja mengonsumsi makanan enak karena merasa aman dengan obat-obatan yang dikonsumsinya. ${ }^{26}$

\section{Pengaruh edukasi dengan pendampingan terhadap kadar trigliserida dan LDL}

Kebiasan makan gorengan, sumber karbohidrat, makanan manis berlebih menyebabkan peningkatan kadar trigliserida dan LDL. Responden masih sulit mengontrol emotional eating sehingga menjadi penyebab rendahnya perilaku responden dalam menjalankan diet yang diberikan. ${ }^{27}$

Asupan karbohidrat memiliki hubungan yang kuat dengan trigliserida. Di dalam tubuh karbohidrat akan diuraikan dalam bentuk sederhana yaitu glukosa. $\mathrm{Di}$ dalam tubuh glukosa akan diproses untuk menghasilkan energi dan sisanya akan disimpan dalam bentuk glikogen. Jika asupan karbohidrat berlebih dan cadangan glikogen sudah cukup, maka glukosa tersebut akan disimpan dalam bentuk trigliserida melalui proses lipogenensis. ${ }^{28}$ Sejalan dengan penelitian Zhang dan Chu (2018) yang mendapatkan hasil bahwa terdapat sedikit penurunan kadar LDL, namun penurunan tersebut tidak signifikan. Penelitian ini dilakukan pada pasien rawat inap dan rawat jalan di salah satu Rumah Sakit Nanjing, China selama 2 tahun dengan intervensi pemberian model pendidikan yang sistematik. ${ }^{8}$

Berdasarkan hasil penelitian, didapatkan bahwa tidak ada hubungan yang signifikan antara asupan karbohidrat dan lemak dengan nilai $\mathrm{HbA} 1 \mathrm{c}, \mathrm{LDL}$ dan trigliserida. Hal ini mungkin saja terjadi, dikarenakan banyak faktor yang mempengaruhi nilai $\mathrm{HbA} 1 \mathrm{C}$ dan profil lipid terutama LDL dan trigliserida selain dari asupan. Meskipun dalam temuan didapatkan hubungan yang secara statistik tidak bermakna, namun kemungkinan hubungan ini secara klinis tidak dapat diabaikan. Bahwa karbohidrat terutama gula sederhana berperan penting dalam kenaikan nilai $\mathrm{HbA1C}$. Karbohidrat juga berperan dalam pembentukan trigliserida, melalui proses lipogenesis. ${ }^{9}$ Asupan lemak yang tinggi terutama Short Faty Acid (SFA) dapat menyebabkan rusaknya insulin yang pada akhirnya menyebabkan hipertrigliseridemia.

\section{SIMPULAN DAN SARAN}

\section{Simpulan}

Pendampingan pasien rawat jalan DM tipe 2 selama 6 bulan di RSCM hanya mampu mengendalikan kadar HBA1C tetapi belum mampu mengendalikan asupan (karbohidrat, lemak)dan profil lipid darah (LDL, dantrigliserida). Padahal kadar $\mathrm{HbA} 1 \mathrm{c}$ secara nyata $(p<0.005)$ berkaitan dengan kadar trigliserida darah, sehingga bagaimanapun 
upaya memodifikasi perilaku makan seiimbang untuk diabetes perlu dipertahankan.

\section{Saran}

Edukasi dengan pendampingan sepertinya masih sulit untuk menimbulkan kesadaran sendiri dalam melakukan perubahan, terutama pada responden yang sebagian besar usianya masuk katagori lansia. Oleh karena itu penelitian yang serupa perlu dicoba lagi pada karakteristik yang berbeda misal responden yang berusia dewasa muda dengan status bekerja. Perlu diperhatikan kepatuhan minumam obat dan penggunaan terapi insulin sebagai faktor pengendalian kontrol glikemik darah. Instrumentasi penelitian dengan food record juga perlu diperhatikan kembali dengan menyediakan formulir yang lebih mudah dipahami oleh lansia sehingga asupan yang dikonsumsi dapat lebih akurat.

\section{UCAPAN TERIMA KASIH}

Terima kasih kepada Instalasi Gizi RSCM terutama Poli Gizi RSCM dan Departemen Metabolik dan Endokrin RSCM yang telah mengizinkan peneliti memperoleh data penelitian tersebut.

\section{RUJUKAN}

1. Kemenkes RI. Cegah, cegah, cegah : Suara Dunia Perangi Diabetes [Internet]. Biro Komunikasi dan Pelayanan Masyarakat. Jakarta; 2018. Available from: http://www.depkes.go.id/article/view/181212 00001/prevent-prevent-and-prevent-thevoice-of-the-world-fight-diabetes.html

2. Riskesdas 2018. Hasil utama riskesdas 2018. Jakarta; 2018.

3. Yuliani F, Oenzil F, Iryani D. Hubungan Berbagai Faktor Risiko Terhadap Kejadian Penyakit Jantung Koroner Pada Penderita Diabetes Melitus Tipe 2. fk Unand. 2014;3(1):37-40.

4. Riddle MC, Bakris G, Blonde L, Ahmann AJ, Barbour LA. Standards of medical care in diabetes. Diabetes Care. 2006;29(2):476.

5. PERKENI. Pedoman pengelolaan dan pencegahan diabetes melitus tipe 2 dewasa di Indonesia 2019 [Internet]. PB. PERKENI. 2019. 1-117 p. Available from: https://pbperkeni.or.id/wpcontent/uploads/2020/07/Pedoman-
Pengelolaan-DM-Tipe-2-Dewasa-di-

Indonesia-eBook-PDF-1.pdf

6. Astari R. Hubungan Antara Kepatuhan Terapi Diet dan Kadar Gula Darah Puasa pada Penderita Diabetes Melitus Tipe 2 di Wilayah Kerja Puskesmas Purnama Pontianak. IOSR J Econ Financ [Internet]. 2016;3(1):56. Available from: https://www.bertelsmann-

stiftung.de/fileadmin/files/BSt/Publikationen/ GrauePublikationen/MT_Globalization_Rep ort_2018.pdf\%0Ahttp://eprints.Ise.ac.uk/434 $47 / 1 /$ India_globalisation $\% 2 \mathrm{C}$ society and inequalities\%28lsero\%29.pdf\%0Ahttps://ww w.quora.com/What-is-the

7. Zareban I, Karimy M, Niknami S, Haidarnia A, Rakhahani F. The Effect of Self-care Education Program on Reducong HbA1c Leves in Patients with Type 2 Diabetes. J Educ Health Promot [Internet]. 2014;3(123). Available from: ncbi.nlm.nih.gov/pmc/articles/PMC4275624

8. Zhang $Y$, Chu L. Effectiveness of Systematic Health Education Model for Type 2 Diabetes Patients. Int J Endocrinol. 2018;2018.

9. Haimoto $\mathrm{H}$, Watanabe $\mathrm{S}$, Komeda M, Wakai $\mathrm{K}$. The impact of carbohydrate intake and its sources on hemoglobin A1c levels in Japanese patients with type 2 diabetes not taking anti-diabetic medication. Diabetes, Metab Syndr Obes Targets Ther. 2018;11:53-64.

10. Annisa A. Hubungan Asupan Serat, Asupan Lemak, dan Riwayat Diabetes Melitus Keluarga dengan Kadar HbA1c Anggota Klub Prolanis DM Tipe 2 di Kota Padang Tahun 2018 [Internet]. Universitas Andalas. 2018. Available from: scholar.unand.ac.id/35621

11. Koloverou E, Panagiotakos DB. Macronutrient Composition and Management of Non-Insulin-Dependent Diabetes Melitis (NIDDM) : A New Paradigm for Individualized Nutritional Theraphy in Diabetes Patient. J Soc Biomed Diabetes Res [Internet]. 2016;1(13):6-16. Available from:

ncbi.nlm.nih.gov/pmc/article/PMC5291179

12. Kirana DN. Hubungan Asupan Nutrisi dengan Kadar Trigliserida pada Penderita DM Tipe 2. 2018;(6).

13. Hanif DB. Hubungan Asupan Karbohidrat Terhadap Kadar Trigliserida pada Penderita Diabetes Melitus Tipe II Rawat Jalan di RSUD Sukoharjo. 2016;

14. Badan-Ribeiro AP. Triglycerides: Frequently Asked Questions. Food 
Bioprocess Technol [Internet]. 2011;1-7. Available from: http://www.heart.org/idc/groups/ahamahpublic/@wcm/@sop/@smd/documents/dow nloadable/ucm_425988.pdf

15. Ugwu CE, Ezeanyika LUS, Daikwo MA, Amana R. Lipid Profile of A Population of Diabetic Patients attending Nigerian national Petroleum Corporation Clinic, Abuja. African $J$ Biochem Res. 2009;3(3):066-9.

16. VinodMaahato $R$, Gyawali $P$, Psd.Raut $P$, Regmi P, Singh KP, Pandeya DR, et al. Association Between Glycaemic Control and Serum Lipid Profile in Type 2 Diabetic Patient: Glycated Haemoglobin as a Dual Biomarker. Fajar [Internet]. 2011;22(3):37580. Available from: http://srirahmayuli.com/konsep-investigasiwabah-dan-kejadian-luar-biasa-klb

17. Hussain A, Ali I, ljaz M, Rahim A. Correlation between hemoglobin A1c and serum lipid profile in Afghani patients with type 2 diabetes: hemoglobin A1C prognosticates dyslipidemia. Ther Adv Endrocrinologi Metab. 2017;8(4):51-7.

18. Kementarian Kesehatan RI. PERMENKES No. 28 Tahun 2019 Tentang Angka Kecukupan Gizi yang Dianjurkan untuk Masyarakat Indonesia [Internet]. Kementerian Kesehatan Republik Indonesia. 2019. Available from: https://barnard.edu/sites/default/files/inline/s tudent_user_guide_for_spss.pdf\%0Ahttp://w ww.. bm.com/support\%0Ahttp://www.spss.co $\mathrm{m} / \mathrm{sites} / \mathrm{dm}$ -

book/legacy/ProgDataMgmt_SPSS17.pdf\% OAhttps://www.neps-

data.de/Portals/0Norking

Papers/WP_XLV.pdf\%0Ahttp://www2.psy

19. Latifani D. Pengaruh Konseling Gizi Dengan Panduan Modul Terhadap Pengetahuan , Sikap, Dan Asupan Makronutrient Pada Wanita Prediabetes Usia 35-50 Tahun. Universitas Diponogoro. Universitas
Diponogoro; 2016.

20. Mardiati SM, Sitasiwi AJ. Pertambahan Berat Badan Mencit (Mus musculus L.) Setelah Perlakuan Ekstrak Air Biji Pepaya (Carica papaya Linn.) Secara Oral Selama 21 Hari. Bul Anat dan Fisiol. 2016;1(1):75.

21. Suarya LMKS, Rustika IM, Astiti DP. Psikologi kesehatan [Internet]. Bali: Prodi Psikologi Kesehatan UDAYANA; 2017. 19 p. Available from: http://journal.unnes.ac.id/sju/index.php/ujph

22. Pasmawati H. Pendekatan Konseling Untuk Lansia. Syi'ar. 2017; Vol.17(No 1):49-60 HIm.

23. Burke SD, Sherr D, Lipman RD. Partnering with diabetes educators to improve patient outcomes. Diabetes, Metab Syndr Obes Targets Ther. 2014;7:45-53.

24. Bloomgarden $Z$. Is insulin the preferred treatment for $\mathrm{HbA} 1 \mathrm{c}>9 \%$ ? J Diabetes. 2017;9:814-6.

25. Kurukulasuriya LR, Sowers JR. Therapies for type 2 diabetes: Lowering $\mathrm{HbA} 1 \mathrm{C}$ and associated cardiovascular risk factors. Cardiovasc Diabetol. 2010;9(45):1-13.

26. Safitri IN. Kepatuhan Penderita Diabetes Mellitus Tipe II Ditinjau dari Locus of Control. J IIm Psikol Terap. 2013;01(02):273-90.

27. Wahyuningsih R, Candri NPA, Faridha SNA. Pengaruh Edukasi Gizi (Diet Rest) Dan Senam Kreasi Unsur Sasak (Tari Rudat) Terhadap Perubahan Berat Badan, Imt, Dan Profil Lipid Pada Mahasiswa Kelebihan Berat Badan Di Jurusan Gizi Politeknik Kesehatan Mataram. J Kesehat Prima. 2018;12(2):124-33.

28. Smith $\mathrm{CM}$, Marks $\mathrm{AD}$, Lieberman $\mathrm{M}$ a. Marks 'Basic Medical Biochemistry: A Clinical Approach, 2nd Edition [Internet]. 2nd Editio. Vol. 34. Philadelphia: Lippincott Williams and Wilkins; 2005. Available from: http://www.ncbi.nlm.nih.gov/pubmed/21638 727 